\title{
GROUNDWATER FLOW IN CRYSTALLINE CARBONATES (JESENIKY MTS., CZECH REP.): USING STREAM THERMOMETRY AND GROUNDWATER BALANCE FOR CATCHMENT DELINEATION
}

\author{
PODZEMNI TOK V KRISTALINSKIH KARBONATIH (POGORJE \\ JESENIKY, ČEŠKA REP.): UPORABA TOKOVNE TERMOMETRIJE \\ IN BILANCE PODZEMNE VODE ZA OMEJNITEV ZALEDIJ
}

\author{
Jan KUKAČKA ${ }^{1,3}$ \& Viola ALTOVÁ2 ${ }^{2}$ \& Jiří BRUTHANS ${ }^{3}$ \& Ondřej ZEMAN ${ }^{3,4}$
}

\begin{abstract}
UDC 556.3(437.1)

Jan Kukačka, Viola Altová, Jiří Bruthans \& Ondřej Zeman: Groundwater flow in crystalline carbonates (Jeseniky mts., Chech Rep.): Using stream thermometry and groundwater balance for catchment delineation

Strips of metamorphosed carbonate rocks in a contact-karst area in the Jeseniky Mts, Czech Republic, act as aquifers, draining broad areas of crystalline rocks, mostly phyllites. Significant groundwater resources that are partly used as a water supply are in carbonate rocks. Detailed temperature and conductivity measurements coupled with discharge measurements along all streams in the area demonstrate a relatively quick method to locate virtually all important groundwater outflows from carbonates. Discharge measurements of streams crossing carbonate strips enabled us to locate and quantify the capacity of ponors and losing parts of streams in various water stages. Thanks to a detailed knowledge of losing and gaining parts of streams, we were able to select appropriate profiles to separate catchments with differing hydrologic balances (balanced, gaining, losing). Flow directions in carbonates and recharge and discharge areas were delineated by comparing the specific discharges of individual catchments. Resulting flow directions agree with tracer tests in the area. Our outlined approach can be used in many other areas to locate hidden inflows into streams and to estimate flow between individual small catchments, and it may partly compensate for tracer tests as it allows flow directions to be estimated from hydrological balance and rock geometry. Keywords: karst, carbonate, limestone, hydrogeology, groundwater.
\end{abstract}

Izvleček UDK 556.3(437.1) Jan Kukačka, Viola Altová, Jiři Bruthans \& Ondřej Zeman: Podzemni tok $v$ kristalinskih karbonatih (pogorje Jeseniky, Češka Rep.): Uporaba tokovne termometrije in bilance podzemne vode za omejnitev zaledij

Ozki pasovi metamorfozoranih karbonatnih kamnin na območju kontaktnega krasa pogorja Jeseniky na Češkem delujejo kot vodonosnik, ki drenira obsežno območje kristalinskih kamnin, predvsem filitov. V karbonatnih kamninah so pomembne zaloge podzemne vode, ki jih deloma izkoriščajo za vodooskrbo. Podrobne meritve temperature in prevodnosti predstavljajo skupaj z merjenjem pretokov vzdolž vseh tokov znotraj območja relativno hitro metodo za določitev položaja praktično vseh pomembnih iztokov podzemne vode iz karbonatov. Merjenja pretokov tokov, ki prečkajo ozke karbonatne pasove, so nam omogočila, da smo določili položaj in ocenili izdatnost ponorov in odsekov površinskih tokov $\mathrm{z}$ izgubami ob različnih hidroloških pogojih. Zahvaljujoč natančnem poznavanju odsekov toka $\mathrm{z}$ izgubami in dotoki smo lahko izbrali ustrezne profile za ločitev zaledij z različnimi hidrološkimi bilancami (uravnotežena, s presežki, z izgubami). Smeri pretakanja $\mathrm{v}$ karbonatih ter območja napajanja in praznjenja so bila določena na osnovi primerjave specifičnih pretokov posameznih prispevnih zaledij. Ugotovljene smeri toka se ujemajo $\mathrm{z}$ rezultati sledilnih poskusov na tem območju. Predstavljeno metodo je možno na različnih območjih uporabiti za določitev položaja skritih dotokov $\mathrm{v}$ tokove in oceno toka med posameznimi manjšimi prispevnimi zaledji, vsaj deloma pa lahko nadomestijo sledilne poskuse, saj omogočajo oceno smeri toka na osnovi hidrološke bilance in geometrije kamnin.

Ključne besede: kras, karbonat, apnenec, hidrogeologija, podzemna voda.

\footnotetext{
${ }^{1}$ Dekonta a.s., Volutová 2523, 15800 Prague 5, Czech Republic, jan.kukacka@centrum.cz

${ }^{2}$ Charles University in Prague, Faculty of Science, Department of Physical Geography and Geoecology, Albertov 6, 128 43 Prague 2, Czech Republic, viola.altova@centrum.cz

${ }^{3}$ Charles University in Prague, Faculty of Science, Department of Hydrogeology, Engineering Geology and Applied Geophysics, Albertov 6, 12843 Prague 2, Czech Republic, bruthans@natur.cuni.cz

${ }^{4}$ PROGEO s.r.o., Tiché údolí 113, 25263 Roztoky, Czech Republic, ondrejzeman@seznam.cz

Received/Prejeto: 21.11.2007
} 


\section{INTRODUCTION}

This study focuses on the hydrogeology of a contactkarst area developed in metamorphosed carbonates in a mountainous terrain (Jeseniky Mts, Czech Republic). Significant water resources in the carbonate strips were suggested by Řezníček (1990). The purpose of this study was to locate all springs and outflows from carbonates, to estimate the flow directions in carbonate rocks, and to delineate recharge and discharge areas.

Thermometry, a simple but highly effective method, was used to locate and quantify concentrated discharge. Flow directions were estimated using hydrology balance calculations rather than tracer tests due to high numbers of recharge and discharge points and the relatively simple geometry of the carbonates.

\section{GEOGRAPHY AND GEOLOGY OF STUDY AREA}

The study area is located in the northwestern part of the Jeseníky Mountains in the northeastern Czech Republic (Fig. 1) at altitudes of $400-1,000 \mathrm{~m}$ a.s.l. The mean annual air temperature $\left(3\right.$ to $\left.7^{\circ} \mathrm{C}\right)$ depends on altitude. Annual precipitation ranges from $880 \mathrm{~mm}$ at lower elevations to $1,109 \mathrm{~mm}$ on mountain summits. Mean regional runoff, based on data from the Bělá River at the Mikulovice gauging station (located ca. $14 \mathrm{~km}$ from the confluence of the Staříč and the Bělá River; figure not shown), is $18.5 \mathrm{ls}^{-1} \mathrm{~km}^{-2}$. Net groundwater recharge (mean annual groundwater runoff) is estimated at 5 to $10 \mathrm{ls}^{-1} \mathrm{~km}^{-2}$ in low- and high-elevation terrains, respectively (Krásný et al., 1982).

The study area is composed of various rocks (phyllite, marble, quartzite, crystalline schist) of the Branná Group, which underwent regional low-grade metamorphism during the Variscan orogeny. Individual lithologies form strips and lenses, which are elongated in the NNE-SSW direction (Fig. 1). Rock strips are interrupted by many NW-SE-trending transverse faults

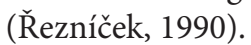

Carbonates have lower amounts of impurities; $60 \%$ of samples have $\mathrm{CaCO}_{3}$ contents $>90 \%$. Carbonates are fine- to medium-grained (grain size $0.1-0.2 \mathrm{~mm}$ ). The porosity of exploited carbonates ranges between $0.7-1.1 \%$ (Toul and Augusta, 1972).

The carbonates are karstified. Superficial karst phenomena are scarce and restricted to ponors and several dolines, while underground karst is more evolved. Sixty caves are known in this area, with a total length of passages of about $2 \mathrm{~km}$. The longest one, the Na Pomezí Cave $(\approx$ $1,000 \mathrm{~m}$ ), is open to the public (Král, 1958; Panoš, 1961).

The hydrogeological setting can be characterized as hard rock with two main aquifers:

Fig. 1: The study area and carbonates of the Branná Group (geology simplified after Vocilka, 1973). 
1) karstified carbonate strips with depths exceeding $100 \mathrm{~m}$ (according to well geophysics), and

2) shallow crystalline rock systems significantly permeable to only a few tens of meters below the ground surface (bgs).

Carbonate strips are continuous for distances of several kilometers and are dissected by important trans-

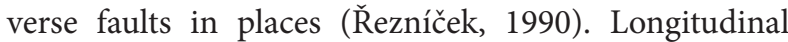
faults show low permeability. Major NW-SE-trending transverse faults, which divide carbonate strips into separate groundwater basins, are hydrodynamically significant. Some transverse faults drain surrounding crystalline rocks into carbonates (Řezníček, 1990). Based on well pumping tests, transmissivities of the carbonates are highly variable $\left(1.10^{-6}-1.10^{-1} \mathrm{~m} 2 \mathrm{~s}^{-1}\right.$; Bruthans, 2006).
The detailed karst hydrology of the area was studied by Panoš $(1961,1962)$, who performed several tracer tests in the karst strips of the Braná Group. Zeman et al. (2003) performed 3 tracer tests in the karst strips in the northern part of the study area using sodium chloride dye methods. The maximum flow velocity in karst conduits is typically 0.1 to $6 \mathrm{~km}^{\text {day }}{ }^{-1}$ (Zeman et al., 2003) based on the tracer tests. The test results suggest relatively large flow volumes and cross-sectional areas of the karst conduits. The mean residence time of groundwater in the crystalline rocks is several years based on a study of two springs and one stream using the environmental tracers ${ }^{3} \mathrm{H}, \delta^{18} \mathrm{O}$, CFCs, and SF6 (Bruthans, 2006).

\section{METHODOLOGY}

Scattered karsts of the Branná Group and their specific conditions demand special approaches. First, a great deal of information about geology, hydrology, hydrogeology, and the terrain had to be collected and studied before field work could be done. GPS methods and topographic maps (1: 10,000 scale) were used for field measurements. Results were analyzed using GIS software.

\section{DISCHARGE MEASUREMENT}

Tortuous flow trajectories in mountainous streams (boulders in riverbeds) preclude using current-velocity meters to measure stream discharge. We used dissolved $\mathrm{NaCl}$ as a tracer to measure discharge (e.g., Kilpatric and Cobb, 1985). The essence of this method is injection of a tracer of known mass (in our case dissolved $\mathrm{NaCl}$ ) into a stream and measuring the concentration downstream. The concentration of added $\mathrm{NaCl}$ was measured by electrical conductivity (Cond 340i, WTW co, Germany, with automatic measurement period $5 \mathrm{sec}$ and automatic compensation to $25^{\circ} \mathrm{C}$ ). For each injection profile, a calibration was performed relating injected $\mathrm{NaCl}$ and changes in conductivity. Three measurements were typically done for each profile and the average value was used (for large differences the measurement was discarded).

\section{COUPLED TEMPERATURE, CONDUCTIVITY AND DISCHARGE MEASUREMENTS OF STREAMS AND INFLOWS}

It is known that most drainage from karst aquifers is via concentrated discharge at springs (Atkinson, 1977). Much of the karst discharge drains directly into streams and thus cannot be measured directly at springs. Such discharges and hidden springs can affect the temperatures and conductivities of streams; thus, the discharges can be located and their yields quantified by measuring stream temperature and electrical conductivity changes. The spacing of measurements was chosen according to stream flow (faster temperature changes in small streams). At each location, both temperature and conductivity were measured at at least three points, in the middle and on both sides of the stream. At springs and other observable inflows, the inflow conductivity and temperature were also measured. Measurements were taken in winter and summer, when the largest contrasts between stream and spring temperatures exist. A considerable advantage of winter measurements is the constant temperature of the streams $(0 \mathrm{oC})$ and the presence of ice crystals in parts of the stream indicating the absence of inflows, thus visually enabling faster progress (Bruthans and Zeman, 2001).

The yield of hidden inflow can be calculated from a formula based on the law of conservation of mass and energy (Bruthans and Zeman, 2001):

$\mathrm{Q}_{1}=\frac{\left(\mathrm{TV}_{2} \times \mathrm{Q}_{2}\right)-\left(\mathrm{TV}_{\text {tot }} \times \mathrm{Q}_{2}\right)}{\mathrm{TV}_{\text {tot }}-\mathrm{TV}_{1}}\left[1 \cdot \mathrm{s}^{-1}\right]$

Explanation:

$\mathrm{Q}_{1}$ unknown yield of hidden inflow (ls- $\left.{ }^{-1}\right)$

$\mathrm{TV}_{1} \quad$ temperature of hidden inflow $\left({ }^{\circ} \mathrm{C}\right)$

$\mathrm{Q}_{2}$ stream discharge above hidden inflow $\left(\mathrm{ls}^{-1}\right)$

$\mathrm{TV}_{2}$ stream temperature above hidden inflow $\left({ }^{\circ} \mathrm{C}\right)$

$\mathrm{TV}_{\text {tot }}$ stream temperature below hidden inflow $\left({ }^{\circ} \mathrm{C}\right)$ 
Conductivity can be substituted in Equation 1 instead of temperature if the conservation of conductivity is valid (changes of conductivity are due only to mixing and chemical reactions are not significant). In ideal conditions, the accuracy of discharge measurement by this method can be $\pm 5 \%$ (Bruthans and Zeman, 2001) depending on the accuracy of temperature and stream discharge measurements. It is important to note that, in many cases, combining discharge and mixing approaches yields better estimates of inflows than using discharge measurements alone. Simply subtracting the measured upstream discharge from the measured downstream discharge can produce larger errors for hidden spring inflows than using the methods described above (Bruthans and Zeman, 2001).

\section{ESTIMATING GROUNDWATER FLOW GEOMETRY IN KARST AQUIFERS}

The study area was divided into 54 catchments on the basis of stream temperature, conductivity, and discharge measurements. ArcGIS 8.3 was used to facilitate data processing. Topographic maps $(1: 10,000)$, geologic maps $(1: 25,000)$, and GPS measurements were used as a base. Individual catchments were delineated in GIS and can be generally classified as one of the following types:

I) Balanced catchments, where no significant groundwater flow to and from other catchments occurs. Only catchments without carbonates were selected for this group. In noncarbonate rocks, the surface catchment is believed to coincide with the groundwater basin as the water table is shallow and generally follows surface topography. Discharge measurement profiles of the

basin stream were made upstream of the first carbonate strip.

II) Losing catchments, where groundwater losses prevail. Such areas included ponors and/or losing stream segments. In some cases, however, the stream does not lose water, but part of the groundwater does not arrive at the stream, instead being diverted to other catchments via carbonate strips. Areas were delineated such that they do not include significant groundwater inflows from other catchments.

III) Gaining catchments, where groundwater gains prevail. Such areas included karst springs and gaining parts of streams. Areas were delineated such that they do not include groundwater outflows to other catchments.

Discharge was measured over short time periods (a few days) during stable water stages (no rain events) on tens of the profiles, which separate individual catchments. Measurements were made repeatedly during different water stages (low and medium water stages).

Figure 2 demonstrates how groundwater balance for individual catchments was calculated from discharge measurements. Balanced catchments A and D (Type I noncarbonate rocks) were used to calculate specific runoff for the measurement period. Runoff was divided by catchment area and averaged. In a second step, balanced specific runoff from $A$ and $D$ were used to calculate expected runoff from other catchments (B and C) by multiplying the balanced specific runoff by catchment area. For $\mathrm{C}$, the measured runoff is about $29 \mathrm{ls}^{-1}$, which is less than the calculated balanced runoff. Hence, about $25 \mathrm{ls}^{-1}$ of water is lost to other catchments via carbonates (Type II). For B, the measured runoff is about $80 \mathrm{ls}^{-1}$, which is

greater than the balanced runoff. Hence, about $29 \mathrm{ls}^{-1}$ of water probably arrives via carbonates from other catchments (Type III). Taking into account the geometry of carbonate strips, the water probably flows from catchment $C$ to catchment $\mathrm{B}$.

Because runoff is also affected by altitude, the average altitude was determined for each catchment and the balanced runoff was calculated based on data from balanced catchments situated at different altitudes.

catchment D specific runoff: $10,51 . \mathrm{s}^{-1} \cdot \mathrm{km}^{-2}$ (non-influenced catchment) discharge: $18,91 . \mathrm{s}^{-1}$

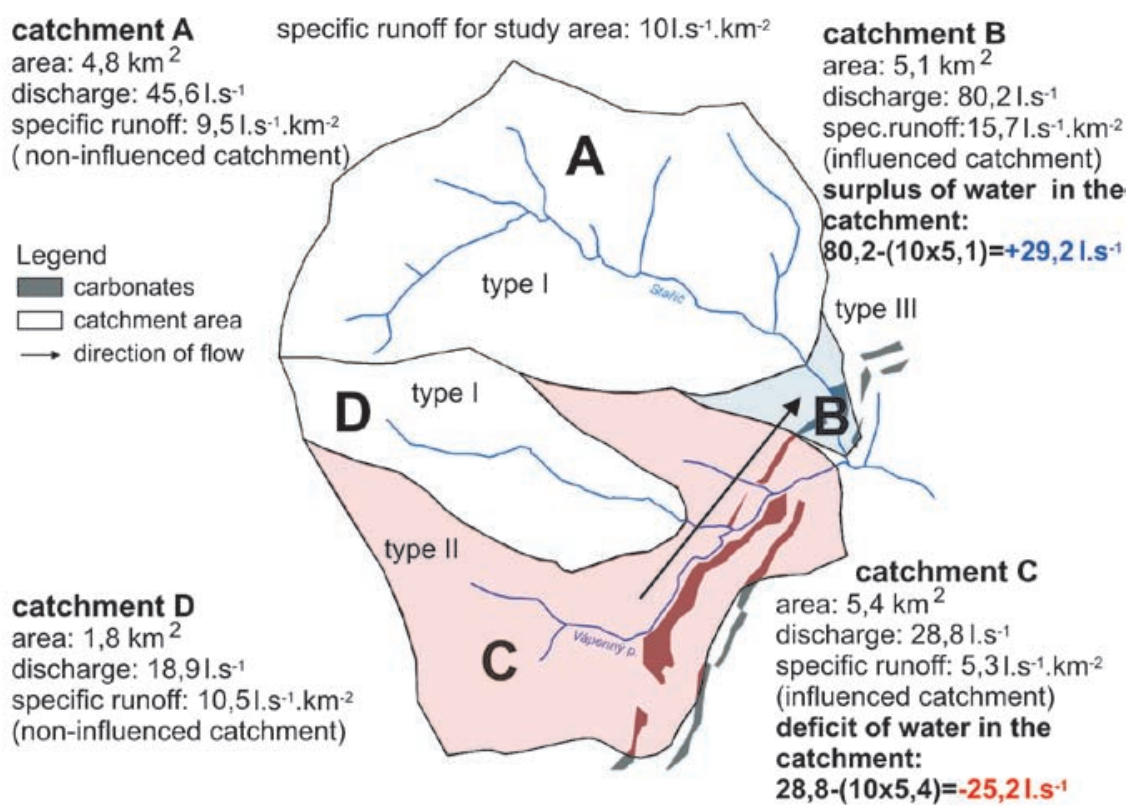

Fig. 2: Estimation of groundwater flow direction in karst aquifers. 


\section{RESULTS AND DISCUSSION}

Many newly found sinkholes and ponors suggest a larger lateral extent of carbonate rocks than currently shown on existing geological maps.

Detailed temperature and conductivity measurements coupled with discharge measurements along all streams helped us locate and quantify concentrated groundwater inflows that were large enough to change stream temperature and/or conductivity. Hidden inflows (groundwater flowing directly to streams) represent tens of percents of total groundwater inflows. Moreover, several major springs were located by thermometry that were unknown or known only to local residents. Many of the springs are partly drained directly to streams. This demonstrates the advantages of thermometry for locating important groundwater outflows from carbonates relatively quickly. For example, the abrupt changes of temperature and conductivity of Ramzovský Brook clearly demonstrates the presence of inflows (Fig. 3).

Discharge measurements of streams above and below carbonate strips helped us locate and quantify the capacities of ponors and losing parts of streams at various water stages. Losing parts of streams are generally located at minor tributaries and headwaters. In some cases, the ponors change to springs during high flow (Lesní Čtvrt' catchment).

Detailed knowledge about losing and gaining parts of streams determined during previous investigations al- lowed us to select appropriate profiles to separate catchments with different hydrologic balances (balanced, gaining, losing, see Fig. 4). About 90 measurements of discharge were made over 10 periods during various water stages.

It was not possible to measure groundwater runoff from carbonates alone. We therefore used the same groundwater runoff rates for carbonates as for other rocks. This is normally a source of error in balance calculations, as carbonates tend to have higher groundwater runoff rates relative to non-carbonate rocks. Because the surface area of carbonates is small relative to other rocks in most of the catchments (less than $10 \%$ of catchment area), we think that this simplification is reasonable and does not result in significant error.

The main areas of groundwater recharge and discharge were located, and their total yield was measured. Some of the spring groups have mean yield around $100 \mathrm{ls}^{-1}$. The largest ponors have capacities around $70 \mathrm{ls}^{-1}$ (Fig. 4).

Flow directions in carbonates and regional recharge and discharge areas were delineated by comparing specific discharge of individual catchments with karst strip geometries (Fig. 4). A regional hydrogeological watershed was located near Ramzová Saddle based on additional data from well water levels. Flow directions estimated from catchment balance calculations agree well with results of tracer tests in areas where data from both methods are available.

Fig. 3: Temperature and conductivity measurements on Ramzovský Brook. 


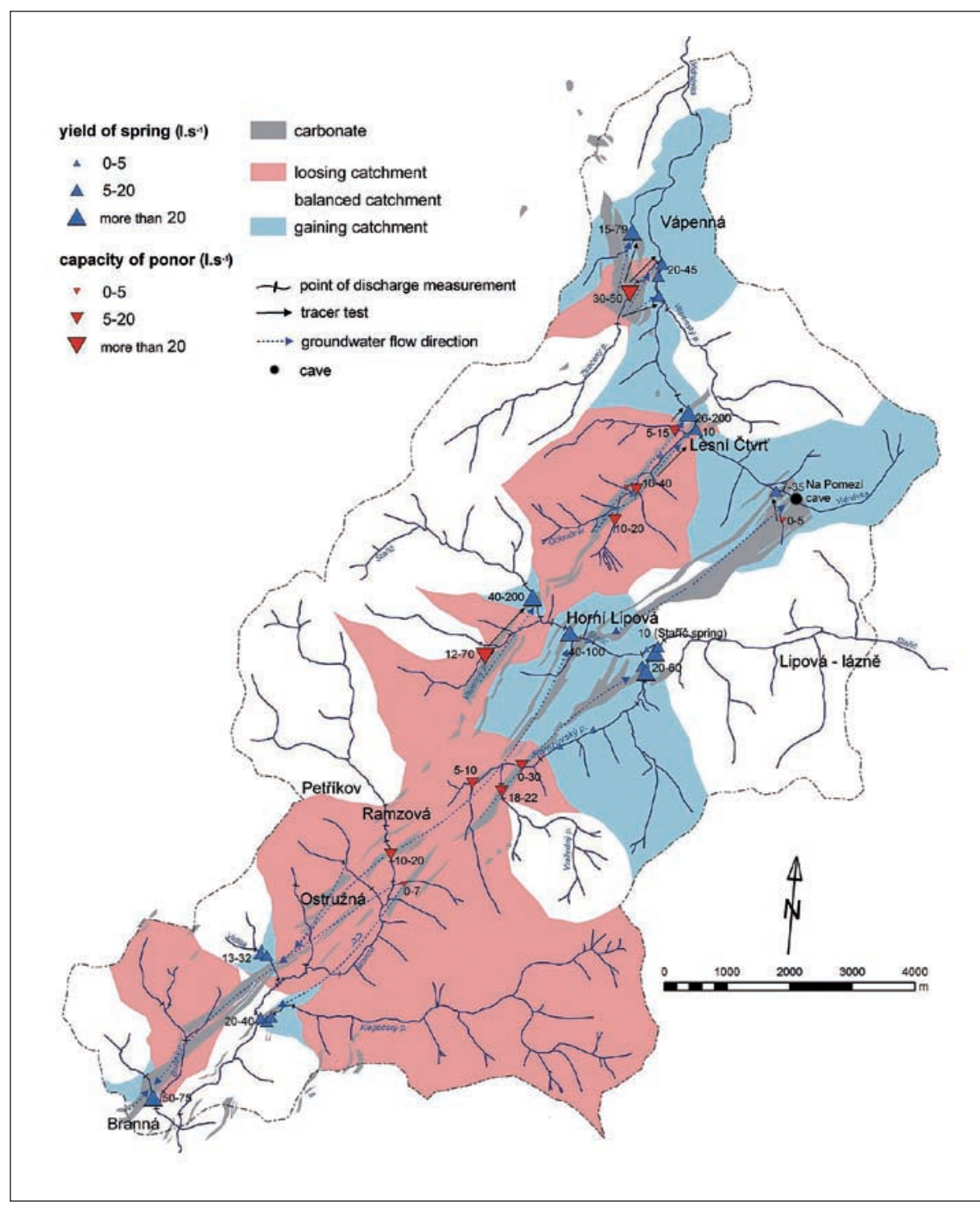

Fig. 4: The groundwater flow direction of study area, the most important springs and ponors and their flow rate and estimation of the catchment character (loosing, balanced, gaining).

\section{CONCLUSIONS}

Detailed temperature and conductivity measurements coupled with discharge measurements along all streams in the area represent a suitable method for locating important groundwater outflows from carbonates relatively quickly. Measuring discharge of streams crossing carbonate strips enabled us to locate and quantify the capacities of ponors and losing parts of streams in various water stages. Thanks to detailed knowledge about losing and gaining stream reaches, we were able to select appropriate profiles to separate catchments with different hydrologic balances (balanced, gaining, losing). Flow directions in carbonates and recharge and discharge areas were delineated by comparing specific discharges of individual catchments. Resulting flow directions agree with tracer tests done in the area. This outlined approach can be used in many other areas to locate hidden inflows into streams and estimate flow between individual small catchments. This method may partly compensate for tracer tests as it allows flow directions to be estimated from hydrological balance and rock geometry alone if the local situation permits. 


\section{ACKNOWLEDGMENTS}

Many thanks to Vápenná village for financial support, to CHKO Jeseníky and to all persons who helped us in the field. This study was partly supported by the research project MSM 0021620855 . We would also like to thank Dr. Alan Mayo, Brigham Young University, USA for improving the English of the manuscript.

\section{REFERENCES}

Atkinson, T.C., 1977: Diffuse flow and conduit flow in limestone terrain in the Mendip Hills, Somerset (Great Britain).- J. Hydrol., 35: 93-110

Bruthans, J., 2006: Využití prirozených stopovaču $\left({ }^{18} \mathrm{O}\right.$; ${ }^{3} \mathrm{H}$; FREONY; SF ) a dalších metod pro zhodnocení doby zdržení vod a charakteru proudění v krasových oblastech ČR..- Disertační práce, Přírodovědecká fakulta, Karlova univerzita, 203 str., Praha,

Bruthans, J., Zeman, O., 2001: Regional permeable zones and stream thermometry in karst areas.- 31. IAH Congress: vol. 2: 697-700. Munich.

Kilpatric F.A., Cobb E.D., 1985: Measurement of discharge using tracers.- Techniques of Water-Resources Investigations of the United States Geological Survey, Book 3. Chapter A16. 52 p.

Krásný J., Kněžek M., Šubová A., Daňková H., Matuška M., Hanzel V., 1982: Mapa odtoku podzemní vody ČSSR.- Český hydrometeorologický ústav, 52str., Praha

Král, V., 1958: Kras a jeskynè východních Sudet.- Acta Univ. Carolinae, Geologica 2., 105-159., Praha.

Panoš V., 1961: Zu den karsthydrographischen Problemen der kleinen Kalksteingebiete in Nordmähren und Schlesien. - Mittelungen der Oesterreichischen Geographischen Gesellschaft, 103, II: 158-177. Wien.
Panoš, V., 1962: Výsledky koloračních experimentů a pozorování krasových vod $v$ Severomoravském kraji. Sborník vlastivědného muzea v Olomouci, oddíl A - přírodní vědy č. 5, 13-60, Ostrava.

Řezníček, V., 1990: Ramzovské nasunutí-krystalinikum Regionální HG průzkum I fáze, pitná voda.- Unpubl. report, Geotest Brno 185 s.

Toul, P., Augusta, L., 1972: Závěrečná zpráva z průzkumu a výpočtu zásob na ložisku vápenců Horní Lipová - Pod tratí.- Unpubl. Report, RD Jeseník n.p., 73 str., Jeseník.

Vocílka, M., 1973: Výsledky geologického mapování a souhrn geologických poměrů v sérii Branné s geologickou mapou $v$ měrítku 1:10 000.- Autoreferát disertace. - Universita J.E.Purkyně, Fakulta př́rodovědecká, 21 str., Brno.

Zeman, O., Bruthans, J, Vojtěchovská, A., 2003: Stopovací zkoušky $v$ krasu skupiny Branné $v$ Rychlebských horách.- Geologické výzkumy na Moravě a ve Slezsku v r. 2002, 102 - 105, Brno 
